\title{
THE PRODUCTIVTY IMPROVEMENT OF SEMANGGI TRADER BASE ON THROUGH DESIGN : PRODUCT, PACKAGING, FINANCIAL AND MARKETING DIVERSIFICATION
}

\author{
Yuli Ermawati ${ }^{1}$; Nurleila Jumati ${ }^{2}$ \\ ${ }^{1}$ Fakultas Ekonomi, Universitas Wijaya Putra Surabaya \\ ${ }^{2}$ Fakultas Ekonomi, Universitas Wijaya Putra Surabaya \\ yuliermawati@uwp.ac.id ${ }^{1}$, nurleila@uwp.ac.id ${ }^{2}$
}

\begin{abstract}
Abstrak
Sejak Indonesia dilanda krisis, tidak semua posisi penting UKM ini dapat dipertahankan. Namun dibandingkan perusahaan besar, UKM cukup kuat menahan gejolak krisis ekonomi.. Pecel Semanggi Suroboyo adalah makanan khas lokal Surabaya yang sudah mulai langka namun masih diminati oleh masyarakat. Salah satu UKM yang menjajakan Pecel Semanggi Suroboyo adalah Ibu Siti Nuriyah. Permasalahan yang dihadapi oleh mitra adalah hasil produksi tidak bisa tahan lama (karena keterbatasan IPTEK) dan belum ada diversifikasi, manajemen usaha dan keuangan masih konvensional, pemasaran masih belum menyentuh teknologi informasi.

Tujuan yang akan dicapai adalah hasil produksi bisa lebih tahan lama dan ada diversifikasi produk, manajemen usaha dan keuangan lebih modern dan sistematis, pemasaran menyentuh teknologi informasi.

Metode yang digunakan adalah pendampingan personal terhadap mitra. Rencana yang akan dilakukan oleh tim adalah dengan memberikan pelatihan proses pengelolaan produksi dengan system pengovenan disertai pengemasan dan alternatif diversifikasi produk, pembukuan sederhana, dan pemasaran efektif secara offline maupun online. Setelah itu tim akan mengawal mereka membuat packaging produk yang modern dengan merk yang mereka ciptakan. Lalu mendampingi mereka melalukan pemasaran secara online agar jangkauan pasar mereka lebih luas. Dengan begitu maka pendapatan mereka akan meningkat dan akan meningkatkan pula kesejahteraan mereka.

Hasil dari metode pendampingan yang diberikan adalah yang pertama packaging produk untuk pecel semanggi telah dirubah sedemikian rupa sehingga menjadi lebih tahan lama dan telah ada diversifikasi produk semanggi menjadi bakwan semanggi dan emping semanggi. Yang kedua adalah manajemen usaha menjadi lebih rapi dan didukung dengan pembukuan sederhana yang mulai rutin dilakukan. Yang ketiga adalah packaging produk yang lebih modern dan cantik disertai dengan pemberian merk serta system pemasaran yang sudah online
\end{abstract}

Kata Kunci : Pecel Semanggi, Kuliner khas Surabaya

\section{PENDAHULUAN}

Peranan UKM dalam perekonomian Indonesia dapat dilihat dari kedudukannya pada saat ini dalam dunia usaha. Urata dalam Ediraras,Dharma (2010) membagi kedudukan UKM sebagai (1) pemain utama dalam kegiatan ekonomi di berbagai sektor, (2) penyedia lapangan kerja terbesar, (3) pemain penting dalam pengembangan kegiatan ekonomi daerah dan pemberdayaan masyarakat, (4) pencipta pasar baru dan inovasi. UKM yang sudah go internasional memberikan sumbangan dalam 
menjaga neraca pembayaran melalui sumbangannya dalam menghasilkan ekspor.

Sejak Indonesia dilanda krisis, tidak semua posisi penting UKM ini dapat dipertahankan. Namun dibandingkan perusahaan besar, UKM cukup kuat menahan gejolak krisis ekonomi. Banyak UKM yang tetap memperoleh laba yang tinggi, walaupun pada tahun 1998 selama puncak krisis pertumbuhan ekonomi yang negatif $13.4 \%$ mengakibatkan terjadinya penurunan jumlah unit usaha sebanyak 2,95 juta unit lebih (BPS dan KMKUKM, 2001).

Surabaya adalah kota metropolitan produktif yang berkembang di semua bidang, termasuk di jasa pariwisata dan kuliner. Dan salah satu makanan khas langka yang menjadi ciri khas kota Surabaya dan sulit ditemukan di kota yang lain adalah pecel semanggi. Pecel semanggi yang menjadi makanan khas lokal kota surabaya telah menjadi bagian dari usaha mikro yang memberikan kontribusi bagi pendapatan penduduk di Surabaya khusunya penduduk asli Desa Kendung Benowo di wilayah Surabaya Barat. Karena dari Desa Kendung itulah pusat pedagang pecel semanggi berasal. Kendala yang dihadapi pedagang pecel semanggi adalah lemahnya implementasi dari segi teknologi pada produk dan kemasan, tidak adanya pencatatan dari segi keuangan, selain itu dari segi pemasaran juga masih tergolong konvensional. Kepedulian terhadap pengembangan UKM sudah semestinya menjadi tanggung jawab semua pihak sesuai dengan bidang yang digelutinya.

Dari sudut pandang diatas, beberapa permasalahan yang dapat dirumuskan, yaitu (1)bagaimana upaya peningkatan produktivitas pedagang pecel semanggi dari segi produk? (2)bagaimana upaya peningkatan produktivitas pedagang pecel semanggi dari segi keuangan? (3) bagaimana upaya peningkatan produktivitas pedagang pecel semanggi dari segi pemasaran?

\section{PROFIL DAN PERMASALAHAN MITRA}

Mitra kami adalah Ibu Siti Nuriyah. Dengan pengalaman beliau yang panjang dalam berjualan pecel semanggi membuat beliau mampu bertahan menghadapi persaingan, dan menyebabkan beliau memiliki banyak pelanggan tetap.

Bigliardi et al (2011) menyatakan bahwa inovasi produk, proses dan pemasaran merupakan jenis inovasi yang banyak berlaku pada usaha mikro dan kecil. Hal ini juga yang menjadi sebagian besar permasalahan yang dihadapi oleh mitra

Permasalahan yang dihadapi mitra PPM pedagang semanggi berdasarkan observasi dan wawancara terangkum dalam tabel 1 di bawah ini :

Tabel 1. Permasalahan Mitra Pedagang Semanggi

\begin{tabular}{|c|c|c|c|}
\hline No & $\begin{array}{l}\text { Aspek } \\
\text { Permasalahn }\end{array}$ & Permasalahan & Solusi \\
\hline 1 & $\begin{array}{l}\text { Pengelolaan } \\
\text { Produksi }\end{array}$ & $\begin{array}{l}\text {-Proses } \\
\text { produksi } \\
\text { masih } \\
\text { tradisional / } \\
\text { manual dan } \\
\text { belum } \\
\text { terstandar } \\
\text {-Produk masih } \\
\text { monoton/ tidak } \\
\text { ada } \\
\text { diversifikasi } \\
\text { produk }\end{array}$ & $\begin{array}{l}\text {-Pengelolaan } \\
\text { produksi } \\
\text { terstandar } \\
\text { baik dari segi } \\
\text { kebersihan, } \\
\text { kesehatan, dan } \\
\text { ketahanan } \\
\text {-Adanya } \\
\text { diversifikasi } \\
\text { dari produk } \\
\text { semanggi }\end{array}$ \\
\hline 2 & $\begin{array}{l}\text { Pembukuan } \\
\text { Sederhana }\end{array}$ & $\begin{array}{l}\text { Tidak adanya } \\
\text { pembukuan }\end{array}$ & $\begin{array}{l}\text { Pelatihan dan } \\
\text { pendampingan } \\
\text { pembukuan } \\
\text { sederhana }\end{array}$ \\
\hline \multirow[t]{2}{*}{3} & \multirow[t]{2}{*}{$\begin{array}{l}\text { Packaging } \\
\text { dan } \\
\text { Pemasaran }\end{array}$} & $\begin{array}{l}\text { Packaging } \\
\text { masih } \\
\text { seadanya dan } \\
\text { tradisional }\end{array}$ & $\begin{array}{l}\text {-Packaging } \\
\text { menggunakan } \\
\text { vacuum sealer } \\
\text { dengan } \\
\text { kemasan lebih } \\
\text { modern dan } \\
\text { cantik }\end{array}$ \\
\hline & & $\begin{array}{l}\text { Pemasaran } \\
\text { dengan } \\
\text { dijajakan } \\
\text { secara } \\
\text { berkeliling }\end{array}$ & $\begin{array}{l}\text { Perlu adanya } \\
\text { pelatihan dan } \\
\text { pendampingan } \\
\text { pemasaran } \\
\text { secara offline } \\
\text { dan online }\end{array}$ \\
\hline
\end{tabular}




\section{METODE PELAKSANAAN}

Metode yang digunakan adalah pendampingan personal terhadap mitra. Rencana yang akan dilakukan oleh tim adalah sebagai berikut :

(1) Untuk masalah di bidang produksi, tim akan memberikan pelatihan pengelolaan produksi dengan system pengovenan dan pengeringan serta pengemasan dengan vacuum sealer bertenaga listrik low watt untuk membuat bumbu pecel semanggi dan sayur menjadi lebih tahan lama. Pelatihan tersebut juga disertai cara perawatan vacuum sealer. (2) Untuk masalah keuangan, tim akan memberikan Pelatihan dan Pendampingan Pembuatan Pembukuan Sederhana untuk mengetahui perkembangan usaha mereka.(3) Untuk masalah di bidang pemasaran, tim akan mengawal mereka membuat packaging produk baru yang modern dan praktis dengan merk yang mereka ciptakan. Lalu mendampingi mereka melalukan pemasaran secara offline dan online agar jangkauan pasar mereka lebih luas. Secara Offline produk tersebut akan dititipkan di warung dan supermarketsupermarket dan menyebar kartu nama serta brosur, sedangkan secara online akan dilakukan dengan pembuatan kontak whatsapp dan blog. Untuk pemasaran online akan didahului dengan Pelatihan dan pendampingan IT yang melibatkan mitra dan anak mitra. Dengan begitu maka pendapatan mereka akan meningkat dan akan meningkatkan pula kesejahteraan mereka

\section{HASIL DAN PEMBAHASAN}

Berdasarkan pada analisis situasi atas persoalan yang dihadapi oleh Ibu Siti Nuriyah serta solusi yang ditawarkan guna menyelesaikan persoalan prioritas tersebut, dalam hal ini dilakukan dalam dua tahapan kegiatan meliputi identifikasi dan implementasi IPTEK dan pendampingan penglolaan usaha.

\section{Produksi}

Kotler dan Keller yang dialih bahasakan oleh Bob Sabran (2012 : 143), menyatakan bahwa kualitas produk adalah kemampuan suatu barang untuk memberikan hasil atau kinerja yang sesuai bahkan melebihi dari apa yang diinginkan pelanggan. Hal ini sejalan dengan pemikiran bahwa pelanggan mitra tentu saja tidak ingin produk yang dibelinya akan cepat basi jika dibawa pulang, maka diperlukan solusi untuk lebih membuat produk tahan lama.

Pelatihan dan pendampingan produksi dengan vacuum sealer bertenaga listrik low watt dan dilakukan pengovenan setelah bumbu diolah menjadi solusi permasalahan ini. Percobaan dilakukan berkali-kali dengan menggunakan berbagai cara, maka hasilnya bumbu pecel semanggi dapat bertahan selama 7 hari. Keterbatasan yang masih menjadi kendala adalah bumbu pecel semanggi masih belum bisa kering sempurna.

Selain itu untuk meningkatkan hasil produkstivitas Mitra, inspiring dan pendampingan diversifikasi produk juga dilakukan. Beberapa konsep dan uji coba telah dilakukan untuk menciptakan produk baru selain pecel semanggi. Akhirnya diversifikasi produk jatuh pada bakwan semanggi dan emping semanggi

\section{Pembukuan / Keuangan}

Menurut Ediraras (2010) Pengelolaan keuangan yang baik dan transparan memerlukan pengetahuan dan keterampilan akuntansi secara baik oleh pelaku UKM.

Setelah dilakukan pelatihan dan pendampingan pembukuan sederhana, kini Ibu Siti Nuriyah dibantu anaknya saudari Maryam memiliki pembukuan sederhana secara berkala. Dari hasil pembukuan sederhana ini, beliau akan dapat memantau perkembangan keuangan usaha Beliau.

3. g dan Pemasaran

Packagin

Sistem pemasaran pecel semanggi Ibu Siti Nuriyah pada awalnya masih tergolong konvensional karena Beliau hanya menjajakan 
pecel semanggi dengan berkeliling antara 1 kampung ke kampung lainnya. Pelatihan pemasaran online dilakukan dengan mengajarkan Ibu Siti Nuriyah dibantu anaknya saudari Maryam dan sang cucu Hesti yang duduk di kelas VII (I SMP). Pelatihan secara online dimulai dari pemasaran melalui Whatsapp, Facebook, dan Media Pemasaran lainnya (Bukalapak,OLX). Untuk pemasaran secara offline kami memfasilitasi Mitra dengan membuatkan kartu nama, brosur, banner, dan mengenalkan Mitra untuk menitipkan produknya ke beberapa toko dan supermarket terdekat.
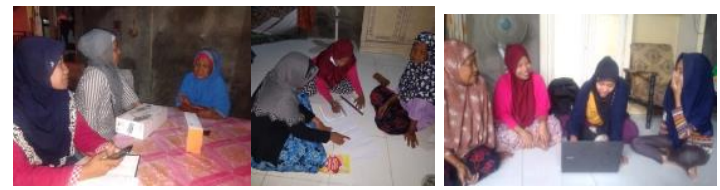

Gambar 1. Pelatihan dan Pendampingan Usaha

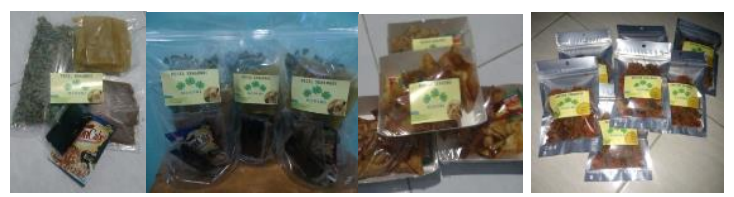

Gambar 2. Hasil Produk Olahan Semanggi

\section{KESIMPULAN}

Melalui proses pelatihan dan pendampingan maka permasalah mitra mulai terjawab. (1)Dari segi produksi, masa ketahanan pecel semanggi menjadi lebih lama. Selain itu terdapat diversifikasi produk semanggi menjadi bakwan semanggi dan emping semanggi, (2)pembukuan sederhana kini secara berkala telah dilakukan dengan bantuan sang anak, (3)packaging/kemasan pecel semanggi, bakwan semanggi, dan emping semanggi menjadi lebih modern, praktis, dan menarik. Selain itu juga terdapat penamaan/merk untuk hasil produksi mitra, (4)pemasaran produk mitra mulai diperlebar dengan dilakukannya pembagian brosur, kartu nama, menitipkan produk ke toko terdekat, whatsapp, facebook, dan media pemasaran online lainnya (Bukalapak dan OLX)
Terima kasih kepada Universitas Wijaya Putra Surabaya yang memberikan dukungan untuk terselenggaranya kegiatan pengabdian masyarakat kepada mitra pecel semanggi Kendung,Benowo,Surabaya

\section{REFERENSI}

Bigliardi, B., Pierluigi, \& Dormio, A. I. (2011). Innovative Caharcteristics of Small and Medium Enterprises. Journal of Technology Management \& Innovation,6(22),83-93

\section{Prasetyawan,Yudha,et all (2014). Peningkatan Produktivitas Usaha Kecil Menengah Kerupuk Udang Melalui Perancangan Pengeringandan Pengemasan. Jurnal metris, 15 (2014), 7-14}

Ediraras, Dharma. Akuntansi dan kinerja UKM. (2010). Jurnal Ekonomi Bisnis. 2 (15), 152-158

Susetyarsih (2012). Kemasan Produk Ditinjau dari Bahan Kemasan, Bentuk Kemasan, dan Pelabelan pada Kemasan. Jurnal STIE Semarang. 4(3), 19-28

Suryana, 2003. Kewirausahaan. Pedoman Praktis. Kiat dan Proses Menuju Sukses. Jakarta: Salemba Empat

\section{UCAPAN TERIMA KASIH}

